\title{
Research on Teacher-Student Interaction in Senior Schools English Teaching in Western China*
}

\author{
LIU Li-ping \\ Leshan Normal University, Leshan, China
}

\begin{abstract}
Interactions in classroom teaching are very important. Through observation and investigation, it is found that teacher-student interaction is the main form of interactions in English classroom teaching in Western China. And there are still some problems in this kind of interaction. Based on questionnaires and the author's observations and her own teaching experiences, this paper discusses the teacher-student interaction in English teaching, exploring and analyzing the reasons of low quality interaction between teachers and students from these aspects: teachers' asking questions, students' talk time, students' initiating questions, the use of multimedia, teachers' use of language etc. It aims to improve the quality of interaction, to improve the efficiency of teaching and learning and to promote students' learning and their whole development.
\end{abstract}

Keywords: teacher-student interaction, senior English teaching, problems, analysis

\section{Introduction}

Many linguists emphasize the great role of interaction in second or foreign language teaching and learning. From their point of view, language acquisition and learning cannot take place without an environment of interaction. This paper focuses on teacher-student interaction in classroom teaching in Sichuan Province in Western China. The author made an investigation in three different types of senior middle schools in Sichuan Province: national-model schools, key-provincial schools, senior secondary schools, knowing about the teacher-student interaction situation in English classroom teaching. The research investigations are based on questionnaires. One hundred and sixty-three copies of questionnaires were delivered to the senior high school graduates who had just left senior schools in the summer of 2011 from different places in Sichuan Province, from which 150 copies were collected, covering different levels of senior high schools in Sichuan, among which 46 students from national-model senior schools, 38 from key-provincial senior schools, and 66 from county-level regular senior high schools and urban regular senior high schools, including some schools in remote and ethnic minority autonomous counties. The research is also based on classroom observations and the author's own teaching experiences in middle schools. The statistics may reflect the situation in teaching in this area to some degree. This paper explores the existing problem of the low-quality teacher-student interaction. The research is based on some theories such as interactionism, second language acquisition theories, etc. It aims to improve the quality of teacher-student interaction and promote students' learning and their whole development.

\footnotetext{
${ }^{*}$ Acknowledgements: This paper is one of the research results of a teaching reform project in Leshan Normal University: The Research of Grinding Course for Normal Students Based on Teacher Professional Community (JG14-YB03). LIU Li-ping, professor, M.A., School of Foreign Languages, Leshan Normal University.
} 


\section{The Existing Problems}

The investigation also relates to these aspects: teachers' asking questions, students' talk time, students' initiating questions, the use of multimedia, teachers' use of the language in instruction, etc. Some problems are obvious through the investigation. The following Table 1 is about the situation of teacher-student interaction in these schools.

Table 1

Teacher-Student Interaction

\begin{tabular}{llll}
\hline Forms of teacher-student interaction & Nation-model & Key-provincial & Senior secondary schools \\
& $\mathrm{N}=46$ & $\mathrm{~N}=38$ & $\mathrm{~N}=66$ \\
\hline Teachers' questions & 11 & 14 & 14 \\
Group work & 4 & 0 & 1 \\
Teachers' explanations & 31 & 18 & 46 \\
Students' doing exercises & 0 & 6 & 5 \\
\hline
\end{tabular}

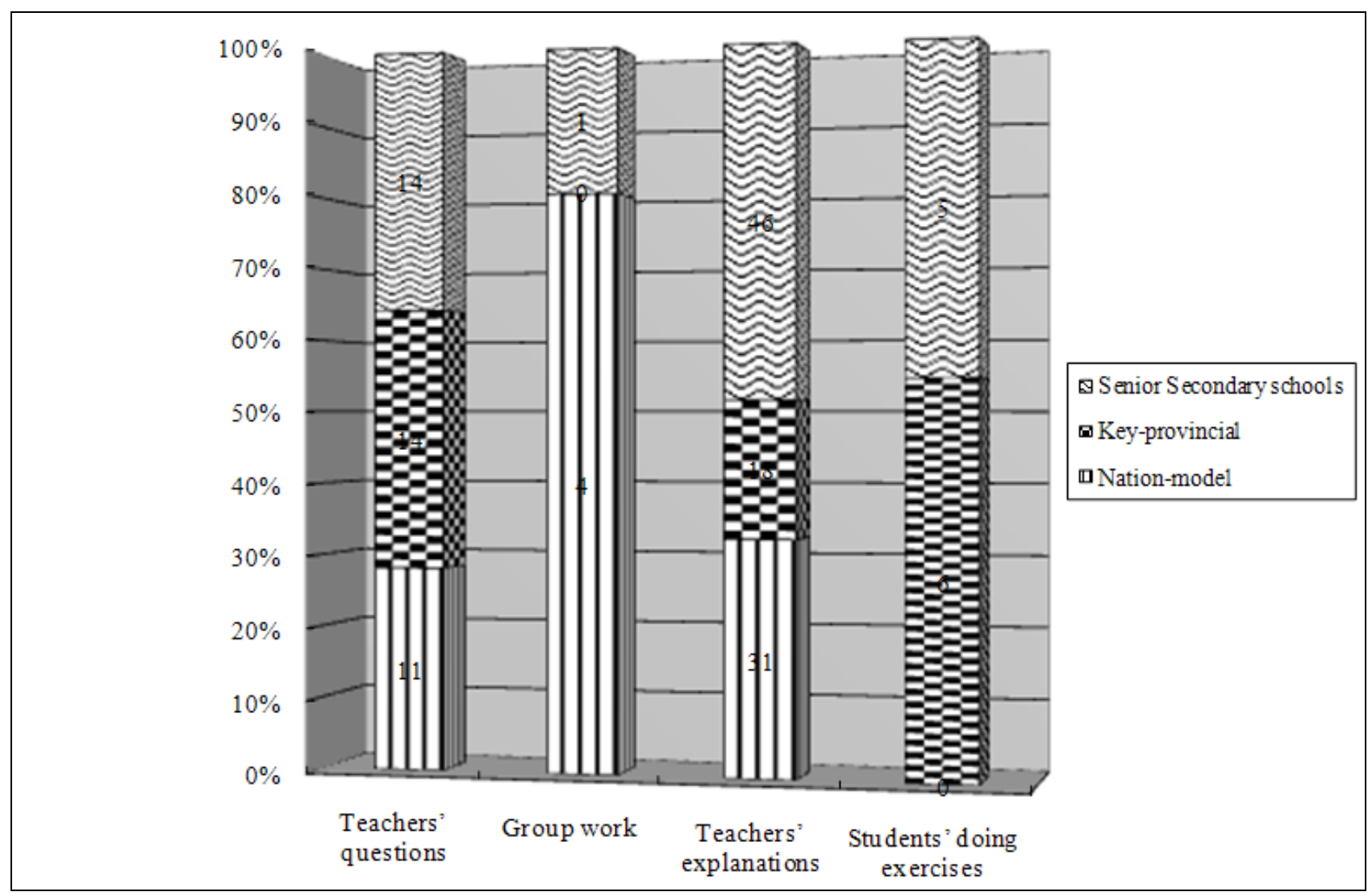

Figure 1. Forms of teacher-student interaction (adopted from LIU, 2012).

From Table 1 and Figure 1 above, the statistics show that 95 students out of 150, which accounts for $63.33 \%$, express that teachers' explanation of the knowledge and students' receipt of what teachers' saying is the main form of classroom teaching. And 39 students out of 150 say that teachers' asking questions is the main form of teacher-student interactions, which accounts for $26 \%$. There is little group work, as only five students say they have group work, accounting $3.33 \%$. It is concluded that teacher-student interaction is the main form 
of classroom interaction in current senior English classes in Sichuan Province. The underlying structure of classroom lessons consequently consists of a sequence of acts, including an initiation act, a response act, and an evaluation act (IRE). Usually the teacher initiates a question; a student responds; and the teacher provides an evaluation. These sequences are easily recognizable in classroom discourse (Johnson, 2000, p. 17). The teacher decides the pattern of communication through a question-answer model of interaction (LIU, 2012).

The problem is that the one way teacher-student interaction will cause low efficiency in teaching; it cannot stimulate learners' enthusiasms in learning; learners will lack critical thinking and risks in asking questions. Littlewood believes this greatly limits the communicative functions that learners need to use and the interactional skills they need to practice (Littlewood, 2000, p. 47).

\section{Theoretical Framework}

\section{Interactionism}

Many linguists from abroad and at home have studied interaction in second or foreign language teaching and learning. Littlewood advocates communicative language teaching (CLT). As interaction is the core of communication, he emphasizes the importance of classroom interaction. He believes that the classroom is also a real social context, where learners and teachers enter into equally real social relationships with each other; once students master language structures and communicative functions, they can transfer them to other kinds of situations (Littlewood, 2000, p. 44). Brown defines interaction as, "the collaborative exchange of thoughts, feelings, or ideas between two or more people resulting in a reciprocal effect on each other" (Brown, 2001, p. 159). He also suggests that from the very beginning of language study, the classroom should be interactive. Barns (quoted in Johnson, 2000, p. 7) believes that classroom learning is a negotiation between teachers' meanings and students' understandings, a sort of give-and-take between teachers and students as they construct shared understandings through face-to-face communication. Johnson believes:

\footnotetext{
Classroom interaction as a dynamic communication... If teachers understand how the dynamics of classroom communication influence second language, students' perception of and participation in classroom activities, they may be better [able to] monitor and adjust the patterns of classroom communication to create an environment that is conductive to both classroom learning and second language acquisition. (Johnson, 2000, p. 3)
}

Rivers believes interaction is so important in language learning situation, in interaction, students can use the language they have learned or casually absorbed in real life exchanges to express their real meaning and they have experience in creating messages from what they hear (Rivers, 2000, pp. 4-5). Teresa, Pica, Richard Young, and Catherine Doughty (1978) found that modified interaction led to higher levels of comprehension than modified input (Lightbown \& Spada, 2002, p. 43). According to Johnson, Interaction Hypothesis claims it is in the interaction process that acquisition occurs: Learners acquire language through talking with others (Johnson, 2000, p. 95). Long suggests that when speakers have the opportunity to receive and participate in conversational adjustments, it maximizes their opportunities for second language acquisition (SLA). He also emphasizes the importance of comprehensible input but places more emphasis on the interaction that takes place in two-way communication and the adjustments that are made as a result of the negotiation of meaning (quoted in Johnson, 2000, p. 83). The negotiation of meaning defined by Ellis, as "the interactive work that takes place between speakers when some misunderstanding occurs, and this will involve saying things again" (Ellis, 1997, p.141). Long states that negotiation provides the learners with two types of linguistic evidence: 
positive evidence (when the interlocutor corrects an utterance by providing the correct form), and negative evidence (when the learner receives feedback on their incorrect output) (Long, 1983, pp. 413-468). Swain also suggests negative evidence promote modified output, that is, push the learner to rephrase and correct his output. A number of applied linguists have suggested that the process of negotiating meaning may be particularly useful to language acquisition.

In China, WU Kang-ling (1998) has done significant research into the interaction that takes place in classroom teaching from the viewpoint of sociology. Many researchers borrow and apply the SLA theories in classroom language teaching in China. Another researcher, WANG Jia-jing's study also shows the importance of classroom interaction. Specifically, if a teacher, students, and the content of teaching in a specific context, interact positively one another, the effects of learning will be satisfactory (quoted in XU, 2005).

\section{Second Language Acquisition Theories}

Krashen and Terrel claim, "we acquire (not learn) language by understanding input that is a little beyond our current level of (acquired) competence" (Krashen \& Terrel, 1983, p. 32). Krashen's claim is that learning will occur when the items the learners will learn are only just beyond their present level, which is called comprehensible input. He describes the acquirer's present level of competence as $i$ and the level immediately following $i$ as $i+1$. The Input Hypothesis claims that learners make progress by understanding language that contains $i+1$. According to the hypothesis, what the learners need as comprehensible input is the simplified codes and rough tuning used by caretakers, a friendly language provider who will rough tune, and modify her language to meet the learners current level.

Swain believes that understanding language and producing language are different skills, and her Output Hypothesis is pushing the learners to produce output - to say and write things (quoted in Johnson, 2002, p. 95).

The notion of interaction is based around a notion that involves both input and output; the learners receive input, and when a learner interacts with someone, he produces output.

Ellis defines negotiation of meaning as, when a learner talks with others, misunderstandings may sometimes occur, negotiation is often the product of interactive exchanges where communication breakdowns take place, so interaction is actually involved in the process of negotiation of meaning. This will involve saying things again with simplified codes. Normally the learner receives interactive modified input, and he also pushes to produce interactive output. He believes negotiation would facilitate processing by giving the learner enough time to focus on both form and meaning, and to map form and meaning (quoted in Johnson, 2002, p. 95). Long claims interactive tasks which promote negotiation of meaning among learners can facilitate the development of a second language acquisition.

\section{Constructivism Psychological Theories}

Bruner observes that the process of constructing knowledge of the world is not done in isolation but rather within a social context. He emphasizes the importance of learners' past learning, stage of development, nature of the material, and individual differences. Effective curriculum then must provide many opportunities and choices for children. In addition, the variety of teaching methods used in the multi-age classroom provides opportunities for children to construct knowledge in a multitude of ways (Bruner, 1983, pp. 129-141).

Dewey calls for education to be grounded in real experience, and he believes inquiry is a critical part of constructivist learning. He also believes learning is an active process in which the learner uses sensory input and constructs meaning out of it; learning is not a passive acceptance of knowledge but that learning involves 
the learners' engaging with the world.

To sum up, Jerome Bruner and John Deway have emphasized cognitive development as being intimately linked to the brain's construction of knowledge within a social context. This view may still engage us in providing the learner with activities, with hands-on learning, with opportunities to experiment and manipulate the objects of the world. The learners construct their knowledge by interacting with the environment. And it at last promotes learners cognitive development.

\section{The Analysis of the Current Situation in Teacher-Student Interaction}

There are some characteristics in teacher-student interaction in these senior schools, and the author will mainly discuss its low qualities, which influence English teaching and learning in Western China.

\section{Teacher-Directed Interaction}

The interaction occurred between a teacher and the students. Teacher-directed means it is the teacher that determines the classroom communicative patterns. Interaction is traditionally teacher to students, one student at a time, occasionally alleviated by some choral work, with all the students repeating what the teacher has said. According to Johnson:

Teachers tend to control the topic of discussion, what counts as relevant to the topic, and who may participate and when. Students tend to respond to teacher directed questions, direct their talk to teachers, and wait their turn before speaking... At any point, however, teachers retain the right to regain control over the structure of classroom communication...play a dominant role in determining the structure of classroom communication. (Johnson, 2000, p. 4)

Through the author's own teaching experiences and her observation in different levels of senior high schools in Sichuan Province, the finding is that teacher-directed interaction is the main form of interactions in English teaching. A teacher often asks students some questions to test whether they understand what he has presented or explained to his or her students, and provides procedural information about how students will be expected to participate in the lesson. It is believed that question-answer mode is a good way to orient the students to the content to be taught because many students would feel embarrassed if they fail to answer the teacher's questions. Rivers claims,

In teacher-oriented interaction, the teacher selects the next speaker and automatically selects him or her for the succeeding turn. There is little motivation for students to listen to one another, and the only motivation to listen to the teacher is the fear of being caught short on an answer. (Rivers, 2000, p. 22)

The ideas of Littlewood and Rivers hold the common beliefs that overemphasis of the teachers' role will take away students' role as active participants in interaction. Teachers should provide students with as many as opportunities to use English.

\section{Form-Focused IRE Model}

Focus on form (in language teaching) is regarded as the traditional approach. Teachers present English language points to students in models, initially one item at a time, in a sequence determined by notions of frequency, valency, or "difficulty" (Long, 1993). And students are required to master each linguistic item. Long believes focus on form lessons tends to be rather dry and may cause at least six major problems: There is no needs analysis to identify a particular learner's or group of learners' communicative needs, and no means analysis to ascertain their learning styles and preferences. It is one-size-fits-all approach. This usually results in teaching too much-some language, skills, and genres learners do not need-and too little-not covering 
language, skills, and genres they do need. This is discouraging to students and inefficient.

Long (1997) also points out that a focus on forms often leads to language usage, not to realistic models of language use. Focus on form ignores language learning processes altogether or else tacitly assumes a long discredited behaviorist model. Leaving learners out of syllabus design ignores the major role they will play in language development. Focus on form tends to produce boring lessons, with resulting declines in motivation, attention, and student enrollments.

Through the author's investigation, she finds that most English classes are form-focused. A teacher has a textbook, which is the main content to be taught, and a teacher may choose some other materials related to the content of the textbook, which are mostly written exercises. A teacher has his teaching model. In a traditional way, a teacher usually teaches the language elements, such as words, phrases, sentence patterns, and then makes his students practice reading and making up some sentences, paying more attention to correcting their errors. The usual way for a teacher to teach a dialogue is as follows: teach the language points, ask his students to read the dialogue, ask students some questions based on the dialogue, ask two students or two groups of students to role play according to their textbooks. However, the students actually recite the content of the dialogue. As for text teaching, some teachers usually always follow the same way; there is no innovation in their teaching day after day and year after year. The result is that students are familiar with their teachers' way of teaching, following the same boring procedures, listening to their teacher passively and taking notes silently, and engaging in exercises on command. Apparently, students are usually spoon-fed. Niu and Wolff (2011) say,

We are merely training parrots! Middle-school teachers use the "talk and chalk" teaching methodology and the parrots err students repeat after the teacher who reads what they have written on the board. Vocabulary is taught in the same manner, with emphasis on memorization, but completely lacking in definitional meaning or contextual usability. (p. 15)

Terdal claims,

Drill, memorization, and correct response epitomize classrooms in much of the world. Students are taught to think the same way, to give the right answer, and to speak only when called upon. Such practices are not compatible with whole language. (Terdal, 1993, p. 28)

We can illustrate this model of teaching in the following Figure 2.

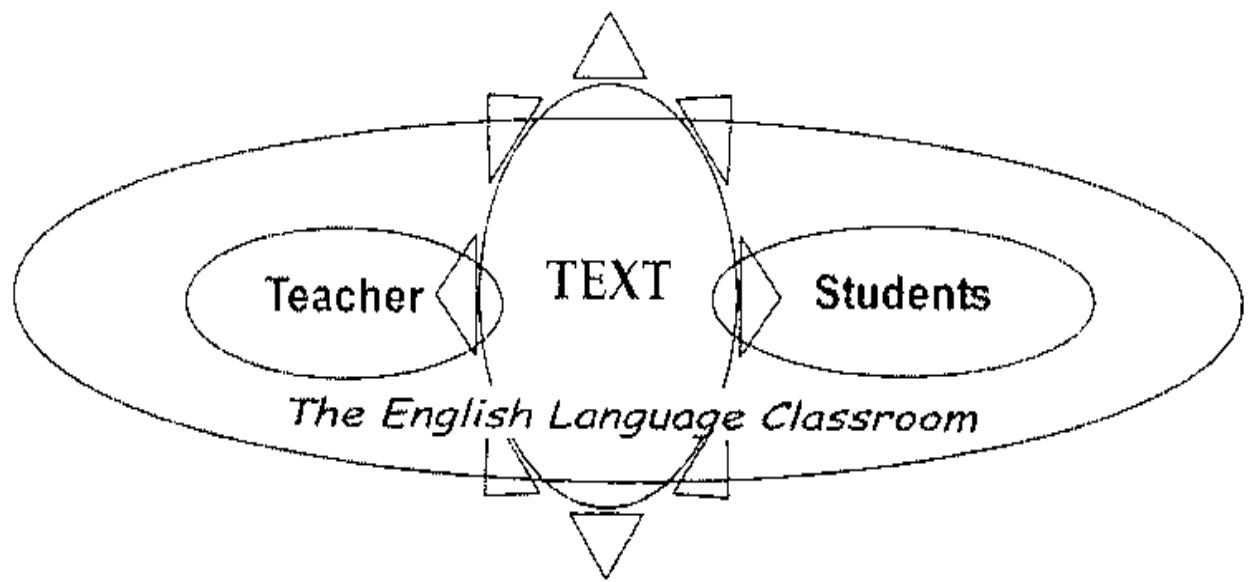

Figure 2. Text-based teaching (Taken from GE Bing-fang, 2006, p. 19).

Form-focused instruction restricts students' active thinking, hindering students' development of creative 
abilities. As students are afraid of making mistakes or errors and avoid being criticized, they are not encouraged to try and take risks, and they are hampered in thinking freely and expressing themselves bravely. Even though they can master English grammatical structure very well, they may make errors when they are speaking as a result of little opportunities to use it. Acquisition requires meaningful interaction in the TL, natural communication, in which speakers are concerned not with the form of their utterances but with the messages they are conveying and understanding. The best methods are therefore those that supply "comprehensible input" in low anxiety situations, containing messages that students really want to hear. These methods do not force early production in the second language, but allow students to produce when they are "ready", recognizing that improvement comes from supplying communicative and comprehensible input, and not from forcing and correcting production.

\section{Insufficient Student Talk Time}

In teacher-centered English class in China, students have little talk time in class, and most of the time, teachers talk more. The following table can indicate this.

Table 2

Students' Talk Time in English Class

\begin{tabular}{lllll}
\hline Time & Talk only by teachers & $2 / 3$ by teachers & Half between Ts-Ss & $2 / 3$ or more by Ss \\
\hline Number of students & 41 & 51 & 38 & 20 \\
\hline
\end{tabular}

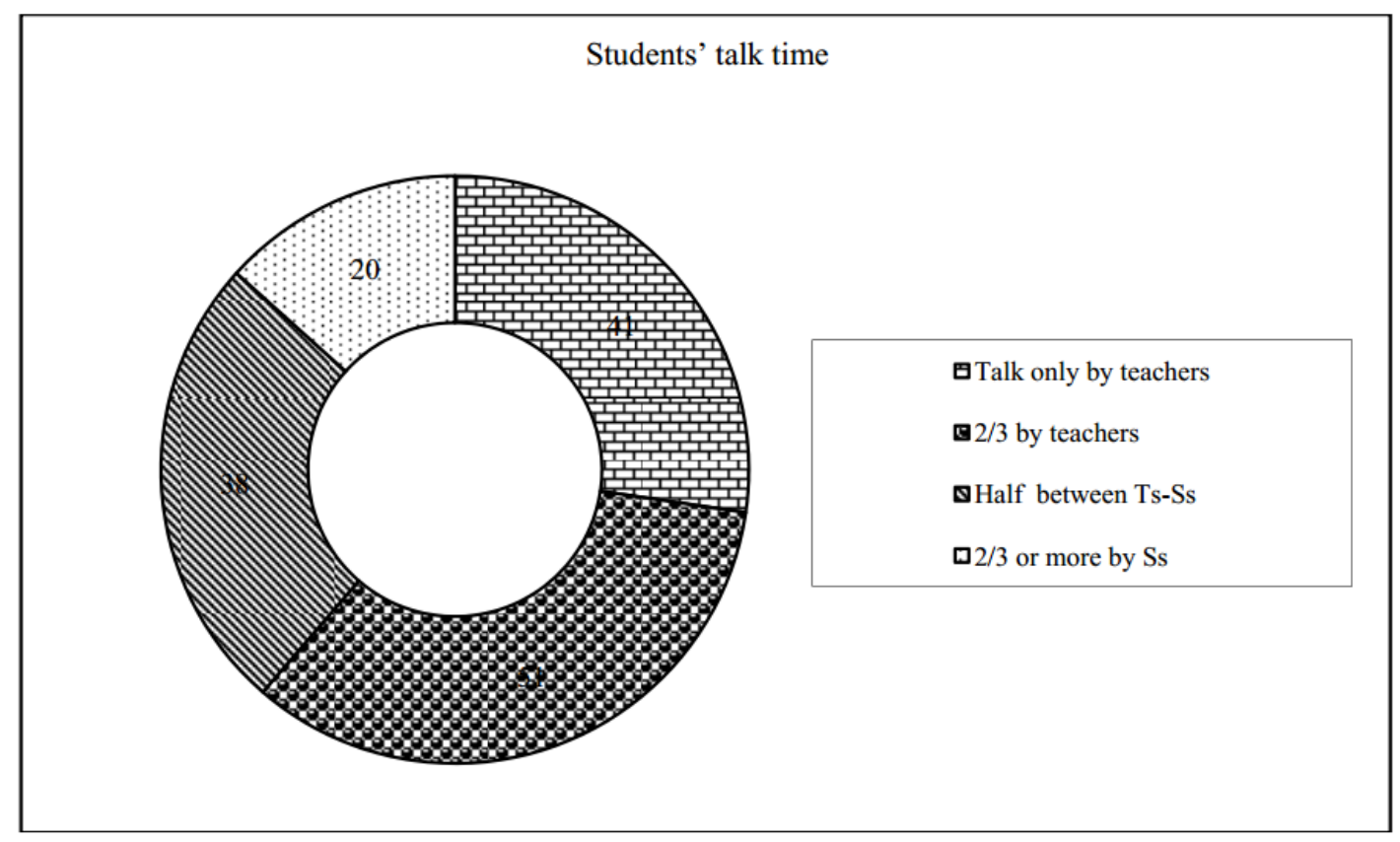

Figure 3. Students' talk time.

Table 2 and Figure 3 show that only 20 students, accounting for 13\%, say their talk time in class reaches or exceeds two-thirds, while 51 students, $61 \%$ of the total, argue that their teachers' talking time is two-thirds of the class time. It indicates that teachers talk most of the time and students have inadequate opportunities to talk in class. Students' talk may include answering teachers' questions, discussing with their teachers or with classmates or initiating questions after careful thinking. Students' small amount of talk time shows that there is 
little active interaction between teachers and students and among students themselves.

Little interaction between teachers and students or among the peers restricts students' thinking. Because interaction can create negotiation of meaning, which can help students construct and reconstruct their knowledge.

According to Vygotsky's socio-cultural theory of human mental processing, the Zone of Proximal Development is optimally achieved when there is support from interaction with a more advanced interlocutor. He assumes that language acquisition actually takes place in the interaction of learners and interlocutor.

Interaction Hypothesis (Allwright, 1984; Long, 1983) claims it is in the interaction process that acquisition occurs: Learners acquire through talking with others. Long (1983) suggests that when speakers have the opportunity to receive and participate in conversational adjustments, it maximizes their opportunities for SLA. He also emphasizes the importance of comprehensible input but places more emphasis on the interaction that takes place in two-way communication and the adjustments that are made as a result of the negotiation of meaning (Johnson, 2002, p. 95). Harmer (2001) suggests that more student-talking time (STT) is needed than teacher-talking time (TTT), for students need the language practice, not the teacher. He also suggests teachers should be aware of how much they themselves are speaking (Johnson, 2002, p. 66). If teachers talk all the time, students will be denied their own chance to practice production, and students may also become bored by listening to the teacher all the time. The important element in STT is students' initiations of questions, including students' responding to the teacher with their own ideas, opinions, reactions, feelings, giving one from many possible answers and students' initiating new questions that are to be answered by their teachers who do not predict before. The common phenomenon is that students answer their teacher's questions; few students initiate questions or express themselves bravely. The statistics below indicate it clearly.

Table 3

Students' Initiation of Questions

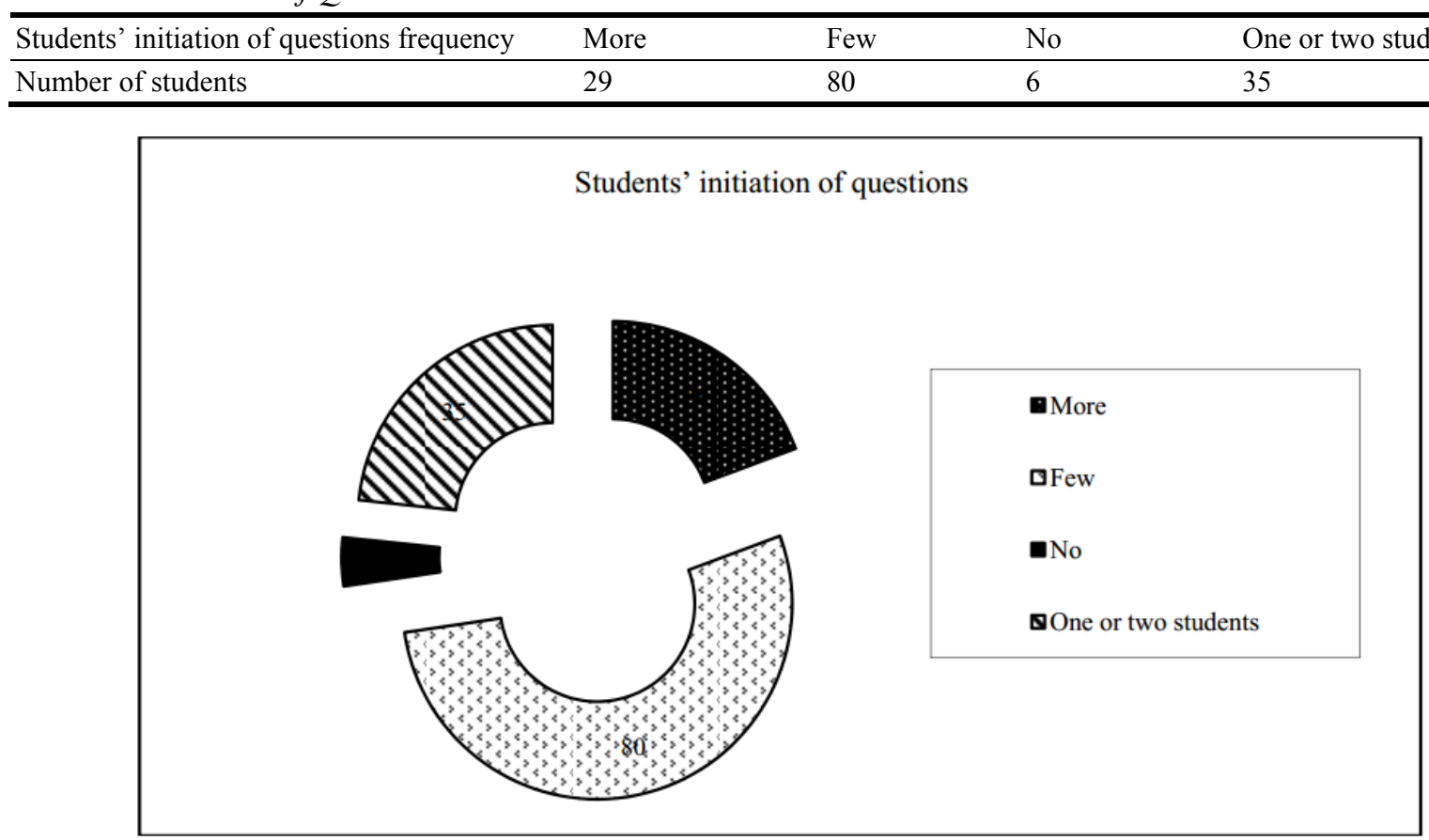

Figure 4. Students' initiation of questions. 
The above statistics show the condition of students' initiation of questions. There are 80 students, or $53 \%$, saying that in English classes few students initiate questions. 23\% of the students say, there is only one or two students occasionally asking questions actively. The reason why so many students do not or are not willing to ask questions may be connected with the teachers' dominant role in teaching: Students are not encouraged to ask questions; students are afraid of making mistakes or errors and losing face before their classmates; students may not have received adequate time given by teachers to think themselves or to discuss with one another and then find problems. In all, the traditional way of teacher-centered teaching has trained students to learn by memorizing, reciting, and doing multiple choices for a long time and gradually they form the habit of receptive learning as their main learning strategy in this kind of class that lacks interaction.

More STT is encouraged in an interactive English class based on the analysis above, which can stimulate students to think in the TL, to learn from each other and correct the errors in the process of negotiating meaning, to cultivate students' cooperative spirits, and to train their personalities.

\section{Shortage of TL Input}

According to the Input hypothesis proposed by Krashen and Terrell, "We acquire (not learn) language by understanding input that is a little beyond our current level of (acquired) competence" (Krashen \& Terrell, 1983, p. 32). Known as the $i+1$ hypothesis, the $i$ represents students' current level of language proficiency, and the 1 represents linguistic competence that is beyond the current one. This hypothesis has great parallels to Vygotsky's Zone of Proximal Development, which claims students need the help of a friendly language provider, who will adjust the complexity of their language accordingly. The adjustment can be rough tune and simplification of the language or focusing on the here and there. Johnson also claims, "By doing so, teachers can create opportunities for students to participate in meaningful interaction (full performance) before they have acquired the necessary skills to do so on their own" (Johnson, 2002, p. 169).

The main factor that restrains interaction is the shortage of comprehensible input in current senior high school English teaching. The input includes language materials, teachers' use of the language, and the methods that teachers adopt to provide students English knowledge. Teachers mainly or totally use the textbook as the main materials of teaching; besides, they choose some exercise or examination papers based on the textbook. There are few authentic teaching materials, such as audio-visual materials, pictures, foreign radio broadcasts, foreign films, and other rich authentic reading and writing materials. Many schools have limited modern education technology, even if there are multimedia, teachers do not use it for English teaching. The following Table 4 indicates teachers' use of multimedia in English classes.

Table 4

The Use of Multimedia $(N=150)$

\begin{tabular}{lllll}
\hline Frequency & Never & Occasionally & Once a month & Once a week \\
\hline Number of students & 84 & 58 & 5 & 3 \\
\hline
\end{tabular}




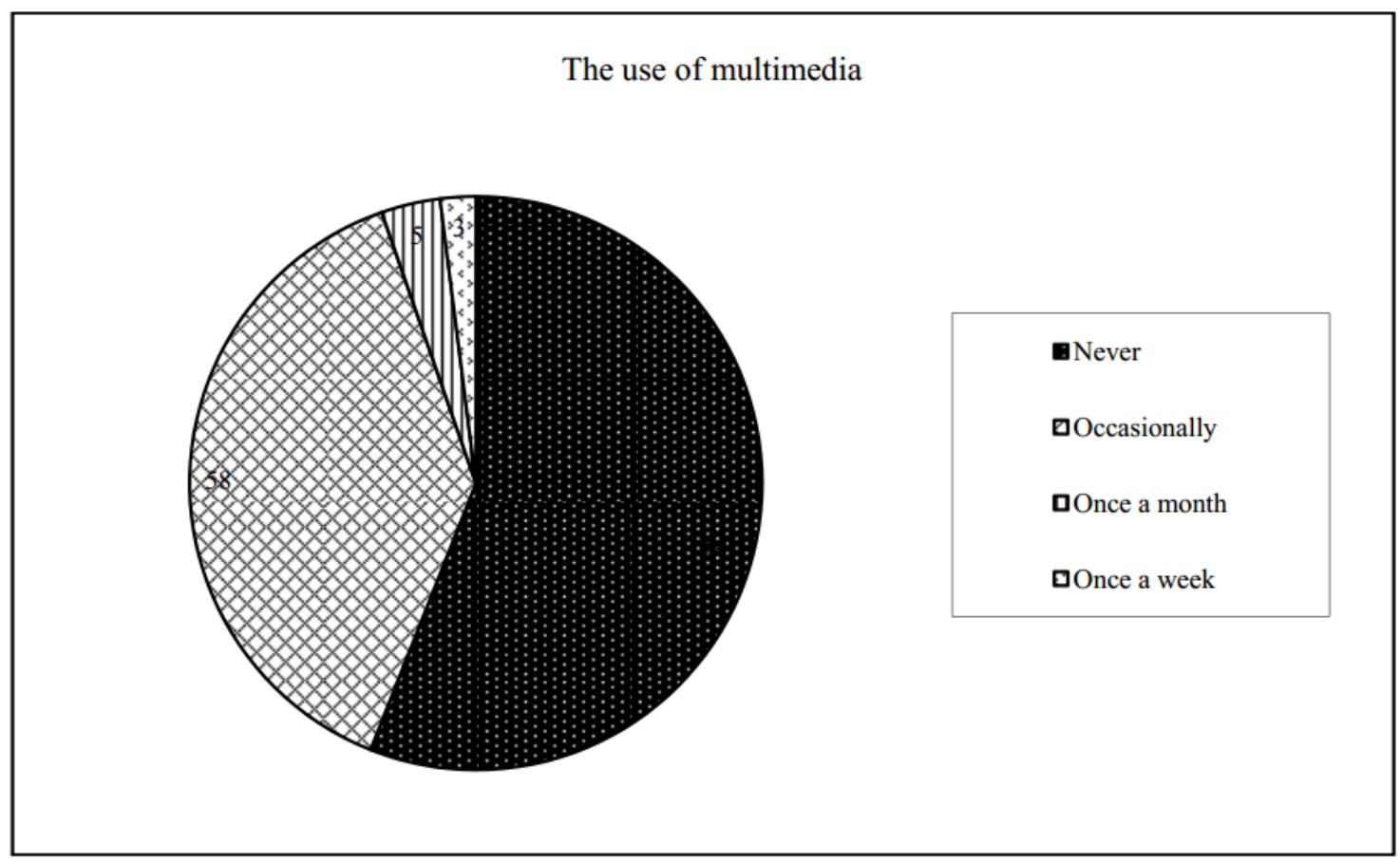

Figure 5. The use of multimedia.

The statistics show that 84 students in 150 , accounting for $56 \%$, say they have never used multimedia in their English classes; 58 students, which is $39 \%$, express that they use multimedia occasionally; only five students say they use it once a month and three students, only $2 \%$, say they use it once a week. As we all know, using multimedia and computers can provide rich language resources to students, especially more authentic information, which can stimulate students' interests, promote students to interact with their teachers and the materials, and hence improve students' English competence and performance. Our government has provided multimedia equipments to schools and has improved the teaching conditions in recent years, however there exists great differences between the urban and the rural schools. The rural schools still lack the good teaching conditions and resources.

Teachers' use of the language refers to what language the teachers of English use as the medium to transmit the TL. The author has attended many English lessons given by different teachers in different levels of senior high schools. She found that many teachers still mostly use their native language to teach the TL, and the students get more Chinese input than English input. As a result, there is an inadequate English learning atmosphere, which hinders students from interacting in English. Harmer suggests that a vital ingredient in their learning of any language is to be exposed to it, and all that anybody needs to learn a new language are those three elements: exposure, motivation, and opportunities for use. So students' lack of English input may affect their thinking in the TL, their constructing of language, and their negotiation of meaning in English (Harmer, 2001, p. 70). At last the insufficient input directly influences the quality of the output.

The ways that teachers use to transmit knowledge are mostly traditional or single, which rarely differ day-by-day and year-by-year. This will hinder the improvement of teaching quality.

\section{Conclusion}

Teacher-student interaction is the main form of classroom instruction in most of English classes in 
Western China. This paper discusses the reasons of low quality of teacher-student interaction based on investigations and theories from these aspects: teacher-directed interaction, focus on language form or its meaning, student-talking time, students' initiation of questions, target language input, the use of multimedia and teachers' use of language, etc. It is important to attach great importance to improving the quality of teacher-student interaction. The ultimate goal to do the research is to improve teachers' ideas and practice in English teaching, and to encourage students to ask questions bravely in classroom teaching. And cooperative learning is also encouraged. So some effective measures should be taken to improve teaching and learning efficiency. The author will continue the further research on the improvement of teacher-student interaction.

\section{References}

Allwright, D. (1984). The importance of interaction in classroom language learning. Applied Linguistics, 5, 156-171.

Brown, H. D. (2001). Teaching by principle: An interactive approach to language pedagogy (p. 159). Beijing: Foreign Language Teaching and Research Press.

Bruner, J. (1983). Education as social invention? Journal of Social Issues, 39, 129-141. Retrieved from http://www.chinaetr.com/Aticle_Show.asp?ArticleID=1466

Deway, J. (1983). Experience and education. New York: Kappa Delta Pi.

Ellis, R. (1997). Second language acquisition (p. 141). Oxford: Oxford University Press.

GE, B. F. (2006). Towards an observation schema for the middle school EFL classroom China English teaching. Beijing: Foreign Language Teaching and Research Press.

Harmer, J. (2001). The practice of English language teaching (p. 70). Harlow: Pearson Education Limited.

Johnson, K. (2002). An introduction to foreign language learning and teaching (p. 95). Beijing: Foreign Language Teaching and Research Press.

Johnson, K. E. (2000). Understanding communication in second language classrooms (p. 17). Beijing: Foreign Language Teaching and Research Press.

Krashen, S. D., \& Terrell, T. D. (1983). The natural approach (p. 32). New York: Pergamon and Alemany.

Lightbown, P. M., \& Spada, N. (2002). How language are learned. Shanghai: Shanghai Foreign Language Education Press.

Littlewood, W. (2000). Communication language teaching. Beijing: Foreign language Teaching and Research Press.

Liu, L. P. (2012). An investigation into typical problems in senior English classroom instruction in China. Sino-US English Teaching, 9(3), 975-981.

Long, M. H. (1983). Native speaker/non-native speaker conversation and the negotiation of comprehensible input. Applied Linguistics, 4, 126-141.

Long, M. H. (1993). Focus on form in task-based language teaching. Retrieved from http://www.chinaetr.com/Article Show.asp?ArticleID=1461

Long, M. H. (1997). The role of the linguistic environment in second language acquisition. In W. C. Ritchie and T. K. Bathia (Eds), Handbook of research on second language (pp. 413-468). San Diego, CA: Academic Press.

Niu, Q., \& Wolf, M. (2011). EFL/ESL teaching in China: Questions-questions-questions. Retrieved April 22, 2016 from https://www.researchgate.net/publication/237506161_EFLESL_teaching_in_China_Questions_-_questions_-_questions.pdf

Rivers, W. M. (2000). Interaction as the key to teaching language for communication. Cambridge: Cambridge University Press.

Swain, M. (1985). Communicative competence: Some roles of comprehensible input and comprehensible output in its development. In S. Gass and C. Madden (Eds), Input in second language acquisition. Rowley, Mass: Newbury House.

Terdal, M. S. (1993). Watching whole language work. TESOL Journal, 2(3), 25-29.

Vigotsky, L. (1978). Mind and society. Cambridge, MA: Harvard University Press.

WU, K. L. (1998). Education sociology (pp. 354-357). Beijing: People Educational Press.

XU, F. (2005). A general review of classroom interaction research abroad and at home. Foreign Language Teaching, 2, 57. 